\title{
ANALISIS SISTEM ANTRIAN MULTIPLE CHANNEL UNTUK KAPASITAS TERBATAS
}

\author{
Joko Susetyo ${ }^{1)}$ dan Siti Rohana Nasution ${ }^{2)}$ \\ ${ }^{1)}$ Fakultas Teknologi Industri, Institut Sains \& Teknologi AKPRIND Yogyakarta \\ ${ }^{2)}$ Fakultas Teknik Prodi Teknik Industri, Universitas Pancasila Jakarta \\ e-mail: joko_sty@akprind.ac.id, siti_rohana@univpancasila.ac.id
}

\begin{abstract}
ABSTRAK
Tingginya arus kedatangan pengunjung pada waktu tertentu dengan kapasitas antrian yang terbatas menyebabkan terjadinya antrian yang panjang. Pengunjung tidak suka untuk menunggu merupakan suatu fenomena yang universal, oleh karena itu dibutuhkan suatu model antrian yang dapat mengurangi panjang antrian dan waktu tunggu pengunjung dengan tetap mengoptimalkan tingkat pelayanan. Salah satu alternatif untuk mengatasi masalah tersebut adalah dengan menggunakan model antrian terbatas, yaitu faktor pembatas besarnya jumlah pengunjung yang dapat dilayani oleh sistem secara nyata yang berarti sistem memiliki kepanjangan yang terbatas. Simulasi merupakan teknik analisis yang secara integrasi dapat memberikan gambaran tentang kondisi pelayanan pada fasilitas pelayanan lesehan secara cepat. Input data berupa waktu antar kedatangan yang berdistribusi Weibull dengan rata-rata 9.5 dan standart deviasi 2.78, waktu pelayanan menu yang berdistribusi Triangular dengan rata-rata 506 dan standart deviasi 11.6, waktu pelayanan kasir yang berdistribusi Beta dengan rata-rata 31.9 dan standart deviasi 6.27. Dari hasil output dapat dilihat bahwa rata-rata panjangnya antrian model usulan adalah 36 pengunjung dalam 25 menit. Dengan rata-rata waktu tunggu maksimal sebesar 6.18 menit. Dari hasil perbaikan model, waktu tunggu konsumen dapat ditekan sehingga antrian yang panjang dapat berkurang.
\end{abstract}

Kata kunci: Simulasi, Model, Antrian.

\begin{abstract}
The high of attending visitor at the ceretain time with the limit queue it cause the long queue. The visitor don't like to wait it's indicate on general, that's why it is need something model that can reduce the long queue and the time of waiting for visitor with the best service. One of the choice to solve this problem is the limit queue that is the limit amount of visitor that that can serve by the real system that means it is have the long limit. The simulation is analyst technique that integrated can give the argumentation about the serve condition to the serve facility in unrolled cafe fast. The input data about the time between attending that distribution Weibull, with the average 9.5 and the deviation standart 2.78, when they serve the menu that is distribution by triangular with the average 506 and deviation standart 11.6, the serve of the cashier that distribution beta with the average 31.9 and deviation standart 6.27. From the result output we can see that the average length of queue of proposal model that is 36 visitor in 25 minutes. With the average waiting time, maximal about 6.18 minutes. From the repairing model, the waiting time of consumer can stress so the long queue can reduce.
\end{abstract}

Keywords: simulation, model, the queue

\section{PENDAHULUAN}

Keberadaan industri di Indonesia, khususnya perkembangan industri jasa menunjukkan pertumbuhan yang signifikan. Industri jasa adalah suatu industri yang didalamnya disediakan satu atau lebih jasa bagi pelanggan [1]. Salah satu contoh industri jasa adalah rumah makan. Rumah makan saling berlomba untuk menawarkan berbagai menu dan pelayanan yang memuaskan pengunjungnya. Pelayanan yang diberikan kepengunjung sering terlambat sehingga mengakibatkan antrian, meskipun dengan jumlah pelayan atau pekerja yang lebih dari satu. Pada umumnya, pengunjung tidak akan memasuki ruang tunggu dengan kapasitas tertentu jika sudah penuh. Hal ini yang mengakibatkan kerugian bagi pemilik rumah makan.

Lesehan Maharani adalah salah satu rumah makan (lesehan) yang banyak diminati oleh konsumen. Pasar potensial rumah makan tersebut berasal dari segala umur, mulai anakanak hingga orang tua. Berbagai kalangan 
mampu membeli dan merasakan pelayanan yang ditawarkan. Seiring berjalannya waktu, konsumen yang melirik Lesehan Maharani semakin bertambah. Pelayanan makanan menjadi masalah, terutama pelayanan makanan yang dipesan oleh konsumen. Beberapa konsumen merasa kecewa karena mereka harus menunggu lebih lama untuk menikmati makanan.

Berbagai masalah tersebut membuat pemilik Lesehan Maharani merasa perlu untuk memperbaiki sistem pelayanannya. Proses pelayanan kekonsumen yang memerlukan waktu lama adalah pemesanan pada jam makan malam. Berbagai solusi untuk mengatasinya sudah diupayakan tetapi jumlah pelayanan tetap belum dapat ditentukan. Penambahan jumlah karyawan yang dibutuhkan sulit diprediksi sehingga pada waktu-waktu tertentu terlihat beberapa karyawan tidak melakukan aktivitas apapun karena permintaan makanan tidak terlalu banyak. Hal ini tentu dapat mengurangi produktivitas karyawan dan dapat mengakibatkan terjadinya pembengkakan pengeluaran. Penelitian ini bertujuan untuk menghitung waktu maksimal pelayanan sehingga waktu tunggu konsumen dapat ditekan serta mengukur parameter dari simulasi sistem nyata yang ada pada lesehan.

Teori antrian adalah teori yang menyangkut studi matematis dari antrianantrian atau baris-baris penungguan [2] Formasi baris penungguan merupakan suatu fenomena yang terjadi jika kebutuhan akan suatu pelayanan melebihi kapasitas yang tersedia untuk menyelenggarakan pelayananan itu. Keputusan untuk menentukan jumlah kapasitas harus dapat ditentukan, walaupun sebenarnya tidak mungkin dapat dibuat suatu prediksi yang tepat mengenai kapan unit-unit membutuhkan pelayanan itu akan datang dan atau berapa lama waktu yang diperlukan untuk menyelenggarakan pelayanan itu.

Dalam pendekatan sistem ada empat faktor yang dominan, yaitu batasan sistem, input, proses dan output [3].

Setiap masalah antrian melibatkan kedatangan, misalnya orang, mobil, atau panggilan telepon untuk dilayani. Unsur ini sering dinamakan proses input. Proses input meliputi sumber kedatangan atau biasa calling population, dan cara terjadinya kedatangan yang umumnya merupakan proses acak (random). Jika di setiap interval tersebut dibagi lagi menjadi $n$ sub interval dengan asumsi dan proses yang sama, maka kedatangan pada setiap interval waktu tetap tersebut dapat dinyatakan dengan distribusi poisson. Dengan demikian, rata-rata kedatangan pelanggan pada setiap waktu menurut adalah [3]:

$\lambda=\frac{N}{I}$

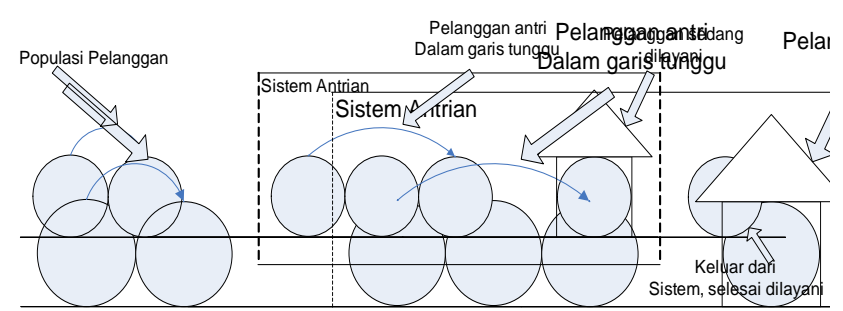

Gambar 1. Sistem Dasar Antrian [3]

Disiplin pelayanan berkaitan dengan cara memilih anggota antrian yang akan dilayani. Begitu pelayanan selesai, maka pelanggan yang membentuk garis tunggu pertama kali segera masuk ke dalam fasilitas pelayanan. Dalam hal ini, aturan sangat jelas, yaitu first come first served.

Proses antrian pada umumnya dikelompokan ke dalam empat struktur dasar menurut sifat-sifat fasilitas pelayanan, yaitu Single channel single phase, Multi channel single phase, Single channel multi phase dan Multi channel multi. Struktur dasar proses antrian seperti yang ditunjukan pada Gambar 2.

Setiap bentuk model garis tunggu pasti mempunyai alasan yang berbeda. Namun yang pasti, ada dua kemungkinan, yaitu: tidak akan terbentuk antrian apabila $\mathrm{n} \leq \mathrm{k}$ atau jumlah pelanggan $n$ paling banyak sama dengan jumlah fasilitas $k$ yang tersedia. Akan terbentuk antrian apabila $\mathrm{n}>\mathrm{k}$ atau jumlah pelanggan $\mathrm{n}$ lebih banyak dibanding jumlah pelayanan $\mathrm{k}$ yang tersedia. Tujuan dari model multi channel single phase adalah untuk memperpendek waktu pelayanan sistem agar waktu di dalam sistem Ws menjadi lebih kecil. Misalnya, rata-rata tingkat pelayanan $\boldsymbol{\mu}$ per jam untuk sebuah 


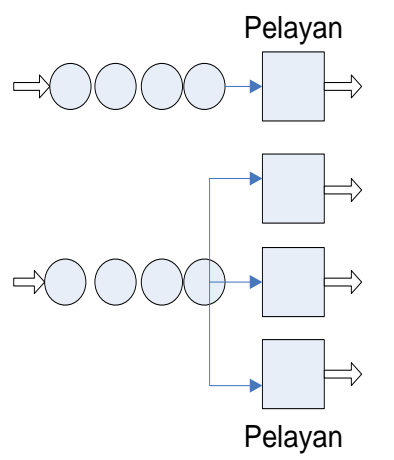

(a)

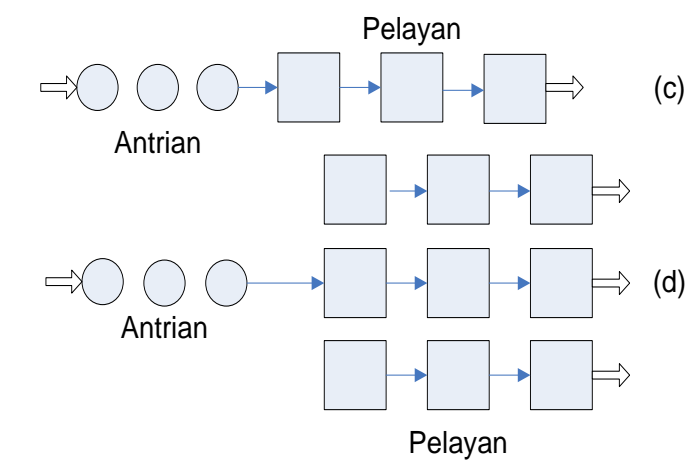

Gambar 2. Struktur Dasar Proses Antrian [3]

fasilitas, maka rata-rata tingkat pelayanan di dalam sistem itu akan menjadi k x $\boldsymbol{\mu}$ per jam untuk k fasilitas.

Ketika setiap penambahan fasilitas mempengaruhi tingkat pelayanan, maka secara rasional tingkat kedatangan ( $\lambda$ ) juga akan terpengaruh, artinya jumlah pelanggan di dalam sistem (Ps) yang sedikit akan menjadi daya tarik pelanggan untuk memasukinya. Karena k fasilitas akan menyebabkan kemampuan sistem naik menjadi $\mathbf{k} \mathbf{X} \boldsymbol{\mu}$ untuk $\mathbf{k}$ fasilitas maka tingkat kesibukan sistem itu akan menjadi [4]:

$\rho=\frac{\lambda}{k \mu}$

Karena sistem memiliki k fasilitas, maka jumlah pelanggan $\mathbf{n}$ yang berada di dalam sistem menjadi parameter yang harus diperhitungkan [4]. Sehingga akan muncul dua kemungkinan yaitu:

Jika $\mathrm{n} \leq \mathrm{k}$ maka

$P_{n}=\frac{\lambda^{n}}{\mu} \cdot \frac{P_{o}}{n !}$

Jika $\mathrm{n} \geq \mathrm{k}$ maka

$P_{n}=\frac{\lambda^{n}}{\mu} \cdot \frac{P_{o}}{k ! k^{n-k}}$

Jadi, sesuai dengan rumus (3), meskipun ada fasilitas yang kosong karena $\mathbf{n}<\mathbf{k}$ maka bukan berarti sistem kosong karena mungkin ada fasilitas yang sedang melayani. Sedangkan menurut rumus (4) mungkin saja hanya terbentuk garis tunggu disatu atau lebih fasilitas, namun ada pula satu atau lebih fasilitas yang lain tanpa garis tunggu.

Karena kemampuan sistem untuk melayani ditunjukan oleh $\mathbf{k} \boldsymbol{\mu}$ lebih lanjut, jika seluruh k fasilitas tidak ada yang kosong atau sedang melayani namun tidak terbentuk garis tunggu. Oleh karena itu, probabilitas pelanggan yang datang harus menunggu karena seluruh $\mathbf{k}$ fasilitas sedang sibuk.

$P n_{(n-k)}=\frac{\lambda^{k}}{\mu} \cdot \frac{P_{o}}{k !\left(1-\frac{\lambda}{k \mu}\right)}$

Probabilitas sistem sedang kosong $\left(\boldsymbol{P}_{\mathbf{0}}\right)$ adalah:

$$
P_{o}=\frac{1}{\sum_{n=0}^{k=1}\left[\frac{1}{n !}\left(\frac{\lambda}{\mu}\right)^{n}\right]+\frac{\frac{\lambda^{k}}{\mu}}{k !\left(1-\frac{\lambda}{k \mu}\right)}}
$$

Selanjutnya, model matematik yang memberi gambaran mengenai kinerja sistem multi channel single phase.

$P_{A}=\frac{\left(\frac{\lambda}{\mu}\right)^{k} \lambda \cdot \mu}{(k-1) !(k \mu-\lambda)^{2}} \cdot P_{o}$

Pada dasarnya, konsep dasar hubungan antara $\boldsymbol{P}_{\boldsymbol{A}}, \boldsymbol{W}_{\boldsymbol{A}}, \boldsymbol{P}_{\boldsymbol{S}}, \boldsymbol{W}_{\boldsymbol{S}}$ di berbagai konfigurasi model dapat dilihat pada Gambar 3.

$P_{A}=\lambda \cdot W_{A}$

Setelah ditemukan $\boldsymbol{W}_{\boldsymbol{A}}$ adalah: 


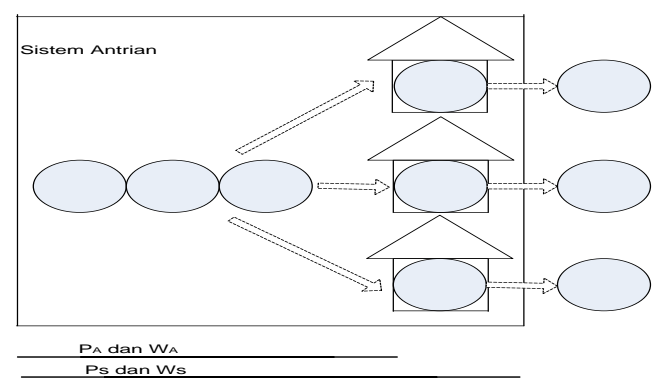

Gambar 3. Model Multi Channel Single Phase [5]

$W_{A}=\frac{P_{A}}{\lambda}$

Di mana: $W_{A}=W_{S^{-}} \frac{1}{\mu}$ atau,

$W_{S}=W_{A}+\frac{1}{\mu}$

Yang terakhir

$$
P_{s}=\lambda . W_{s}
$$

Jika rumus (10) disubstitusikan ke rumus (11), maka bisa ditemukan $\boldsymbol{P}_{s}$ yaitu:

$$
P_{S}=\lambda \cdot\left(W_{A}+\frac{1}{\mu}\right)
$$

Hubungan antara $\lambda$ dengan $\boldsymbol{W}_{\boldsymbol{A}}$ adalah:

$$
\boldsymbol{P}_{A}=\lambda . W_{A} \text { Maka : } \boldsymbol{P}_{S}=\boldsymbol{P}_{A}+\frac{\lambda}{\mu}
$$

Panjang garis tunggu terbatas berarti jumlah pelanggan di dalam garis tunggu dibatasi [6]. Pelanggan tidak masuk jika ruang tunggu dengan kapasitas tertentu itu sudah penuh. Jika didalam sistem ada $\mathbf{M}$ pelanggan termasuk yang sedang dilayani maka keterbatasan ruang tunggu itu akan mempengaruhi $\boldsymbol{P}_{0}$ secara langsung, yaitu:

$$
P_{o}=\frac{1-\frac{\lambda}{\mu}}{1-\left(\frac{\lambda}{\mu}\right)^{M+1}}
$$
adalah:

Rata-rata pelanggan dalam sistem $\left(P_{S}\right)$ 


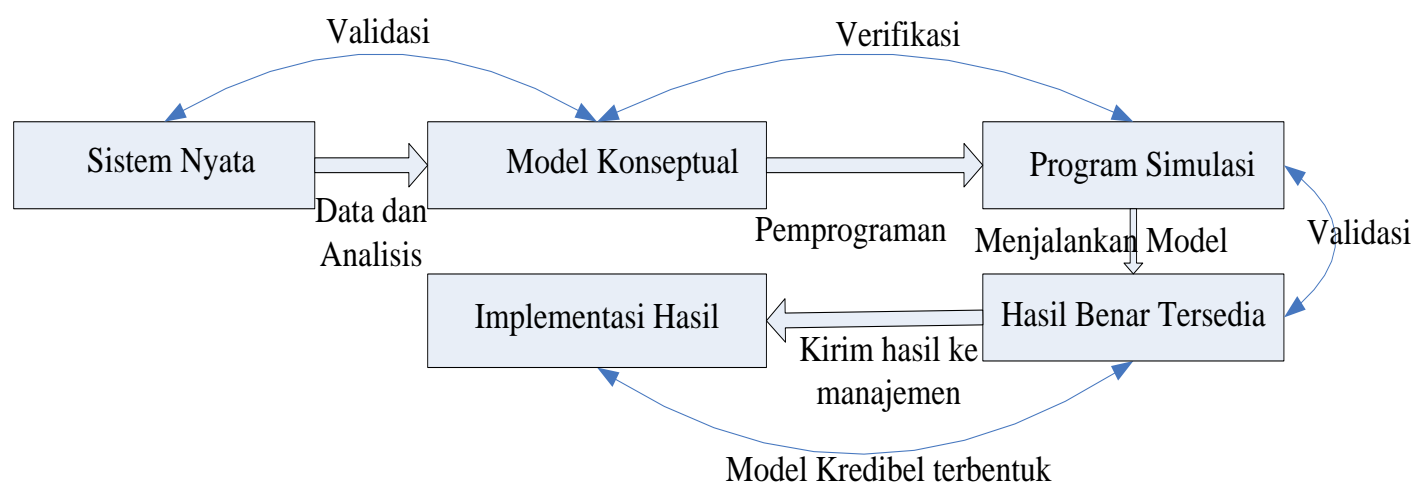

Gambar 5. Relasi Validasi dan Verifikasi [7]

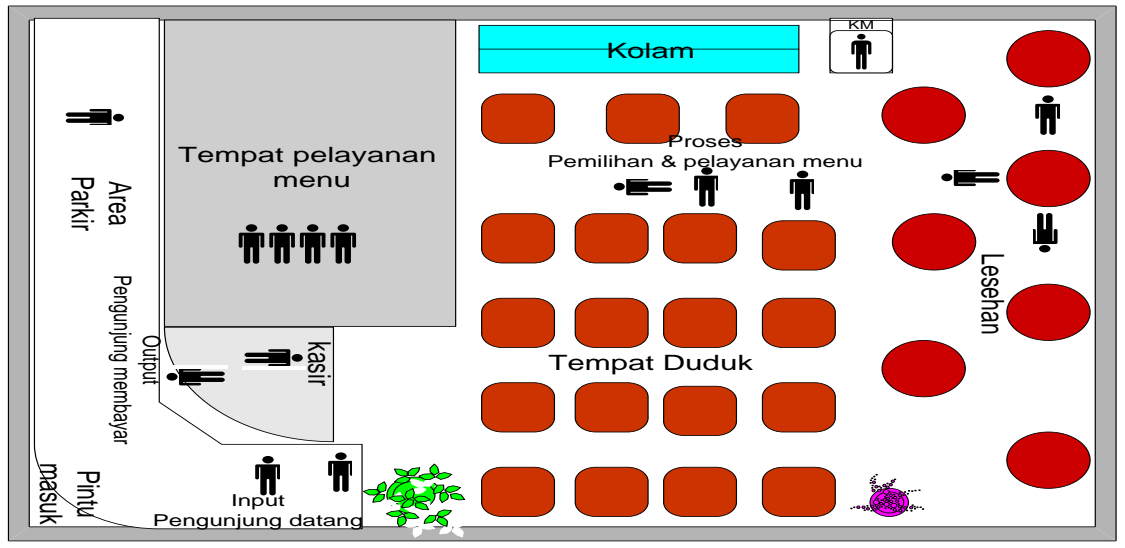

Gambar 6 Sistem Nyata di Lapangan

waktu pelayanan list. Menghitung waktu pelayanan menu makanan. Setelah data terkumpul, dilakukan pengetikan data dengan bantuan software office excell.

\section{HASIL DAN PEMBAHASAN}

Gambar 6 menunjukkan gambar sistematis proses pelayanan pada Lesehan Maharani.

Dari Gambar 6 pengunjung yang datang langsung memasuki pintu masuk Lesehan Maharani untuk menempati tempat duduk yang telah tersedia (90 tempat) baik lesehan maupun kursi. Pengunjung yang telah menempati tempat duduk, akan segera dilayani oleh pekerja dengan memberikan pilihan menu makanan dan minuman. Pengunjung segera memilih dan memesan sesuai dengan selera dan pekerja akan menyediakan menu yang telah dipesan, selanjutnya pengunjung dapat menikmati makanan dan minuman yang telah disajikan. Dari hasil penelitian yang telah dilakukan dan dari hasil data yang didapat selama 2 hari (6 dan
27 Juni 2009) pada pukul 19.00-21.00 WIB adalah sebagai berikut:

\section{Penentuan distribusi}

Dalam pembuatan model, diadakan penentuan distribusi yang tepat dan sesuai dengan masing-masing data yang dicari yaitu: penentuan distribusi pada waktu antar kedatangan pengunjung.

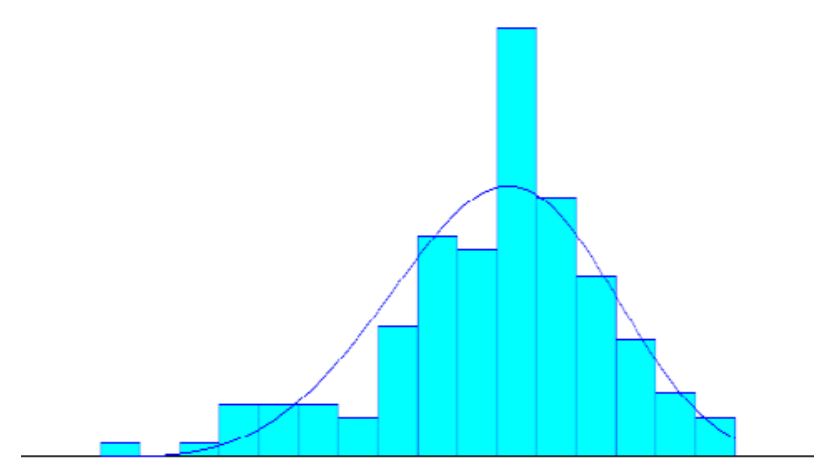

Gambar 7. Distribusi Waktu Antar Kedatangan

\section{Distribution Summary}

Distribution: Weibull 
$\begin{array}{ll}\text { Expression: } & -0.5+\mathrm{WEIB}(11,4.19) \\ \text { Square Error: } & 0.011258\end{array}$

Chi Square Test

Number of intervals $=8$

Degrees of freedom $=5$

Test Statistic $\quad=13.3$

Corresponding p-value $=0.0222$

\section{Data Summary}

Number of Data Points $=144$

Min Data Value $\quad=0$

Max Data Value $\quad=15$

Sample Mean $\quad=9.5$

Sample Std Dev $\quad=2.78$

$\begin{array}{ll}\text { Histogram Summary } & \\ \text { Histogram Range } & =-0.5 \text { to } 15.5 \\ \text { Number of Intervals } & =16\end{array}$

Penentuan distribusi pada waktu pemilihan menu

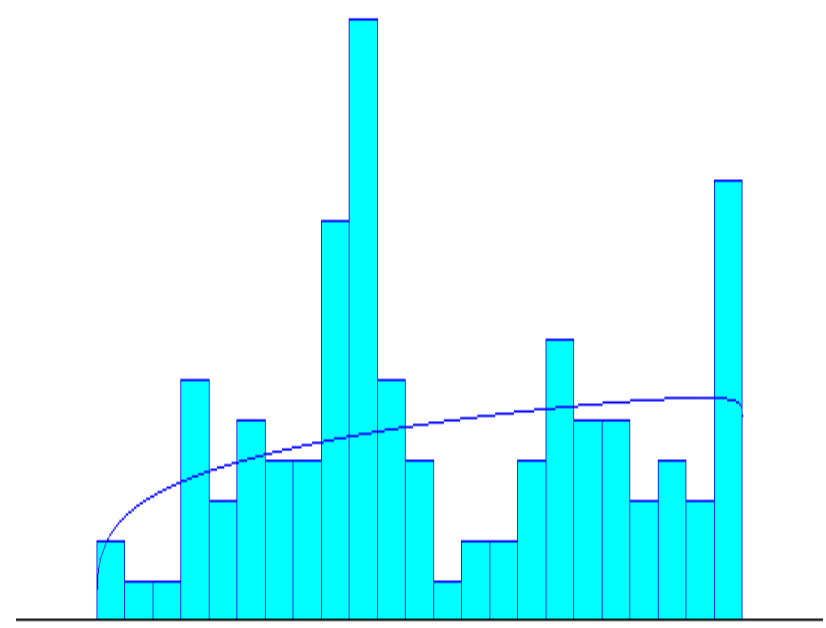

Gambar 8. Distribusi Waktu Pemilihan Menu

Distribution Summary

Distribution: Beta

Expression: $\quad 19.5+23 * \operatorname{BETA}(0,0)$

Square Error: 0.020671

Chi Square Test

Number of intervals $=9$

Degrees of freedom $=6$

Test Statistic $=24.8$

Corresponding p-value $<0.005$
Data Summary

Number of Data Points $=108$

Min Data Value $\quad=20$

Max Data Value $\quad=42$

Sample Mean $\quad=31.9$

Sample Std Dev $\quad=6.27$
Histogram Summary
Histogram Range $\quad=19.5$ to 42.5
Number of Intervals $\quad=23$

Penentuan distribusi pada waktu pelayanan menu makanan

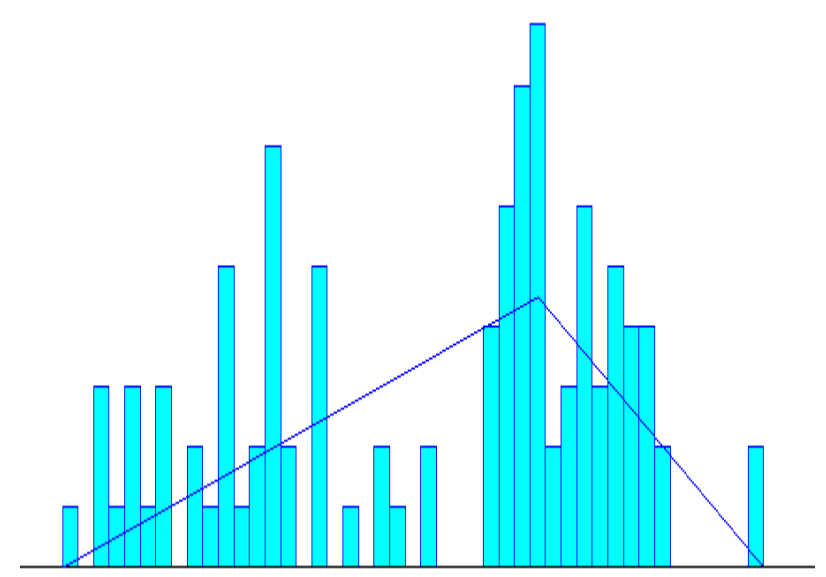

Gambar 9. Distribusi Waktu Pelayanan Menu Makanan

Distribution: Triangular

Expression: $\quad \operatorname{TRIA}(0,0,0)$

Square Error: 0.021198

Chi Square Test

Number of intervals $=8$

Degrees of freedom $\quad=6$

Test Statistic $\quad=42.1$

Corresponding p-value $<0.005$

Data Summary

Number of Data Points $=101$

Min Data Value $\quad=483$

Max Data Value $\quad=527$

Sample Mean $\quad=506$

Sample Std Dev $\quad=11.6$

Histogram Summary

Histogram Range $\quad=483$ to 528

Number of Intervals $\quad=45$ 


\section{Uji kecocokan distribusi}

Uji kecocokan distribusi bertujuan untuk mengetahui tingkat kesesuaian antara fungsi distribusi hasil pengamatan dengan fungsi distribusi teoritik tertentu. Uji kecocokan distribusi dilakukan untuk: waktu antar kedatangan, waktu pemilihan menu, dan waktu pelayanan menu.

\section{Uji Chi-square Goodness of Fit Test}

Kriteria pengujian Chi-square pada dasarnya adalah membandingkan $x^{2}$ hitung dengan $x^{2}$ tabel. Jika $x^{2}$ hitung $<x^{2}$ tabel maka hipotesis nol diterima. $H_{o}$ yang berarti data memang berdistribusi seperti yang disebutkan pada hipotesis nol. Pengujian dengan uji Chisquare adalah sebagai berikut:

$H_{0}$ : Data waktu pelayanan menu berdistribusi

Triangular dengan nilai rata-rata 506

$H_{1}$ : Data waktu pelayanan menu berdistribusi

Triangular dengan nilai rata-rata 506

\section{Tabel 1. Penghitungan $x^{2}$ hitung}

\begin{tabular}{|c|c|c|c|}
\hline \multirow{3}{*}{$\begin{array}{l}\text { Interval } \\
\text { Kelas }\end{array}$} & \multicolumn{3}{|l|}{ Frekuensi } \\
\hline & Observasi & Expected & \\
\hline & $\mathrm{Oi}$ & $\mathrm{Ei}$ & $x^{2}$ hitung \\
\hline $483-488$ & 9 & 13 & -4 \\
\hline $489-494$ & 12 & 13 & -1 \\
\hline $495-500$ & 15 & 13 & 2 \\
\hline $501-506$ & 6 & 13 & -7 \\
\hline $507-512$ & 17 & 13 & 4 \\
\hline $513-518$ & 28 & 13 & 15 \\
\hline $519-524$ & 13 & 13 & 0 \\
\hline $525-530$ & 1 & 13 & -12 \\
\hline & 101 & & -3 \\
\hline
\end{tabular}

\section{Hasil Output Model Usulan}

Tabel 2 merupakan hasil output dari model usulan.

\section{Pembuatan Model Yang Sesuai dengan Sistem Nyata dengan Bantuan Software Arena 10.0}

Pembuatan model ini dilakukan apabila penentuan distribusi telah dilakukan untuk memperjelas distribusi dari masing-masing data yang dicari. Gambar dibawah ini adalah gambar model yang dibuat dengan bantuan software arena 10.0 yang disesuaikan dengan system nyata.
Tabel 2. Hasil Report pada Panel Resources

\begin{tabular}{|c|c|}
\hline Keterangan & Nilai \\
\hline$\sum$ Pengunjung yang masuk & 149 \\
\hline $\begin{array}{l}\text { Total pengunjung yang selesai } \\
\text { pelayanan menu }\end{array}$ & 28 \\
\hline $\begin{array}{l}\sum \text { Pengunjung balking pada } \\
\text { pemilihan menu }\end{array}$ & 23 \\
\hline $\begin{array}{l}\text { Waktu tunggu rata-rata dalam } \\
\text { antrian }\end{array}$ & 1.52 menit \\
\hline Waktu tunggu maksimal & 6.18 menit \\
\hline Waktu tunggu minimal & 0.3292 detik \\
\hline Total waktu tunggu & 5.56 menit \\
\hline $\begin{array}{l}\sum \text { Pengunjung menunggu dalam } \\
\text { sistem }\end{array}$ & $\begin{array}{c}36 \\
\text { pengunjung }\end{array}$ \\
\hline Utilisasi pekerja: & \\
\hline 1. Agung & 0.99 \\
\hline 2. Ali & 0.94 \\
\hline 3. Anton & 0.96 \\
\hline 4. Asep & 0.90 \\
\hline 5. Budi & 0.97 \\
\hline 6. Cindy & 0.90 \\
\hline 7. Doddy & 0.89 \\
\hline 8. Joni & 0.89 \\
\hline 9. Lia & 0.98 \\
\hline 10. Lita & 0.88 \\
\hline 11. Lolo & 0.91 \\
\hline 12 Sita & 0.89 \\
\hline 13. Sinta & 0.05 \\
\hline 14. Ucup & 0.93 \\
\hline 15. Woni & 0.87 \\
\hline
\end{tabular}

Dari Gambar 10 dibuat ke dalam software Arena 10.0 untuk dijalankan dan kemudian dianalisis hasil outputnya [8] untuk melihat nilai waktu rata-rata tunggu pengunjung dan banyaknya pengunjung yang menunggu untuk dilayani. Sebelum menjalankan model terlebih dahulu melihat apakah model yang dibuat tidak ada kesalahannya. Dengan cara sebagai berikut: Klik Run $\rightarrow$ check model $\rightarrow$ jika ada tulisan no errors and warnings in model, maka model dapat dijalankan.

\section{Perbandingan Hasil Simulasi Model Sistem Nyata dengan Simulasi Model Usulan}

Perbandingan Hasil Simulasi Model Sistem Nyata Dengan Simulasi Model Usulan adalah sebagai berikut:

a. Lama waktu tunggu

Selama 25 menit pada sistem nyata terjadi antrian 62 pengunjung dengan lama waktu tunggu 458 detik (7.63 menit) sedangkan 


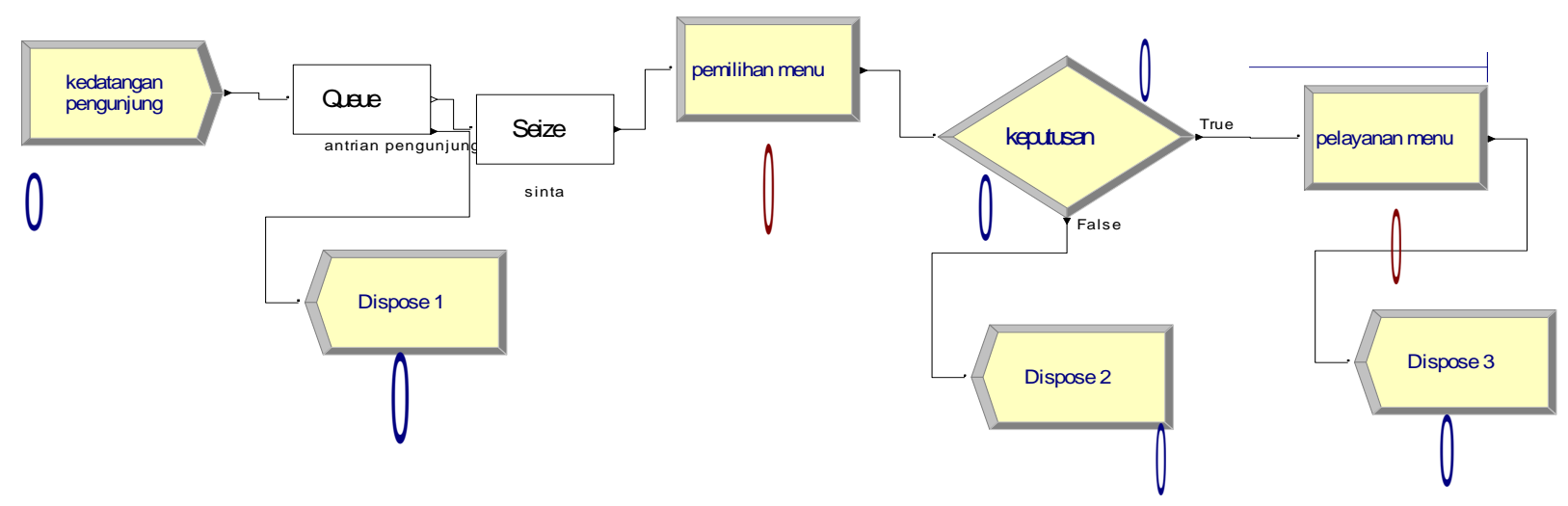

Gambar 10. Model yang Sesuai dengan Sistem Nyata

pada model usulan hanya terjadi antrian 36 pengunjung dengan lama waktu tunggu 333.89 detik (5.56 menit).

b. Waktu tunggu rata-rata

Hasil output model sistem nyata menunjukkan bahwa selama 25 menit terjadi waktu tunggu rata-rata 247.91 detik (4.12 menit) dan mengalami penurunan waktu tunggu rata-rata pada model usulan yaitu sebesar 156.8 detik (2.61 menit).

c. Waktu pelayanan

Selama 25 menit pada model sistem nyata, jumlah pengunjung yang masuk sebesar 153 pengunjung dan yang dapat dilayani hanya 17 pengunjung dengan 8 pekerja. Hasil output menunjukkan bahwa utilisasi pekerja rata-rata 98\%, sedangkan pada model usulan yang masuk sebesar 149 pengunjung dan yang dapat dilayani hanya 51 pengunjung dengan 14 pekerja. Dari penelitian selama 2 jam (pukul 19.00 21.00 WIB) kesibukan pekerja adalah 117.6 menit (1 jam 57 menit).

\section{Analisis Hasil Output}

Hasil output ini memperlihatkan hasil dari menjalankan usulan model yang dibuat dengan bantuan software Arena 10.0 yang disesuaikan dengan model nyatanya. Hasil dari output adalah sebagai berikut:

a. Membaca hasil report pada panel queue

Hasil report pada panel queue secara lengkap. Panel queue memperlihatkan hasil bahwa selama 25 menit terjadi antrian dengan rata-rata 36.09 pengunjung dibaris antrian pelayanan menu dengan lama waktu tunggu 333.89 detik (5.56 menit).

b. Membaca hasil report category by Replication

Hasil dari report category by Replication secara lengkap. Waktu tunggu rata-rata pengunjung adalah sebesar 91.1094 detik (1.52 menit), sedangkan waktu tunggu ratarata pengunjung maksimal adalah 352.56 detik (5.87 menit). Total time maksimal adalah sebesar 371.32 detik (6.18 menit), sedangkan total time minimal adalah sebesar 0.3292 detik.

c. Membaca hasil report pada panel Resources Hasil report pada panel Resources. Selama 25 menit pelayanan, semua pekerja dalam kondisi sibuk terutama pekerja pelayanan menu. Rata-rata kesibukannya sebesar 86,33\% yang berarti tingkat menganggurnya sebesar $13.77 \%$. Dari penelitian selama 2 jam (pukul 19.00 - 21.00 WIB) kesibukan pekerja adalah 103.6 menit (1 jam 42 menit).

d. Verifikasi dan Validasi

Verifikasi dilakukan untuk mengecek apakah program yang dibuat sudah sesuai dengan model yang diinginkan. Dalam Arena telah dilengkapi dengan fasilitas untuk mencari kesalahan dari model yang telah dibuat serta menunjukkan letak kesalahannya dari hasil program yang dijalankan.

Validasi dilakukan untuk mengetahui output model sudah sesuai dengan sistem nyatanya. 
Validasi ini dilakukan dengan cara membandingkan output dari model simulasi sistem nyata dan model simulasi sistem usulan. Validasi ini dilakukan menggunakan uji T dengan bantuan program SPSS. Pada model yang dibuat sudah sesuai dengan sistem nyatanya.

\section{KESIMPULAN}

Kesimpulan yang dapat diambil dari penelitian ini adalah parameter hasil simulasi adalah rata-rata waktu tunggu dalam antrian adalah 1.52 menit untuk setiap pengunjungnya. Rata-rata waktu tunggu maksimal dalam antrian adalah 6.18 menit. Rata-rata panjang antrian adalah 36 pengunjung. Melihat hasil utilisasi pekerja, tingkat kesibukan rata-rata sebesar 86.33\%. Dengan penambahan 6 pekerja pada bagian pelayanan menu, maka total waktu tunggu dan jumlah pengunjung yang mengantri dapat ditekan sampai 50\%.

\section{DAFTAR PUSTAKA}

[1] Arifin, Miftahol, 2008, Simulasi Sistem Industri, Graha Ilmu, Yogyakarta.

[2] Mulyono, S., 2007, Riset Operasi. Lembaga Penerbit Fakultas Ekonomi, Universitas Indonesia.

[3] Siswanto, 2006, Operation Research jilid 2. Erlangga, Jakarta.

[4] Taha, H, A., 1996, Riset Operasi Suatu Pengantar jilid 2, Binarupa Aksara, Jakarta.
[5] Kakiay, T.J., 2003, Pengantar Sistem Simulasi, Andi, Yogyakarta.

[6] Djati, Bonett S.L., 2007, Simulasi Teori Dan Aplikasinya, Andi, Yogyakarta.

[7] D.J.A. Simarmatama, 1985, Operation Research: Sebuah Pengantar TeknikTeknik Optimasi Kuantitatif Dari SistemSistem Operasional, PT.Gramedia, Jakarta.

[8] Kelton, David.W \& dkk, 2004, Simulation With Arena, Third Edition, McGraw-Hill Companies, North America. 